\title{
DEMOGRAPHIC PROFILE OF PENAN STUDENTS IN TWO PUBLIC SECONDARY SCHOOLS AND ACADEMIC ATTAINMENT OF THEIR SCHOOL LEAVERS
}

\author{
Juna Liau \\ Universiti Malaysia Sarawak, Faculty of Social Sciences and Humanities \\ ljuna@unimas.my
}

\begin{abstract}
This article documents the demographic background of Penan secondary school students that are studying in two public secondary schools located at the Baram District in Miri Division, Sarawak Malaysia and the academic achievement of their schools' leavers. Ethnographic research methods which include survey questionnaire, interviews and field observations are used to obtain the data. Data from interviews and observations are analysed thematically and Microsoft Excel is used to analyse data related to demographic profile of students such as their age, gender, village and level of education. Data on the cost of transport used to go to boarding schools and information related to the access to the internet and telephone service are analysed to examine students' mobility and accessibility. Access to social services, including the internet and telephone, is important for all people, including Penan populations. In the context of education, internet access allows for learning to take place at any time, any place and at any pace. Through the data on students' demographic profile and academic achievement of school leavers, the study calls for the understanding of Penan education beyond individuals' agency. This includes the understanding of students' mobility from village to boarding schools which interlinked with the idea that education enables and promotes the acquisition of skills, knowledge and broadens individuals ' horizons. Moreover, pursuing secondary schools outside students' villages provides opportunities for employment outside their villages after the completion of their SPM or STPM examinations; opens a window to advance their education to tertiary level as an attempt to improve their socio-economic status.
\end{abstract}

Keywords: Academic attainment, accessibility, gender, marginalized community and mobility

Copyright: This is an open access article distributed under the terms of the Creative Commons Attribution-NonCommercialShareAlike 4.0 International (CC BY-NC-SA 4.0) license which permits unrestricted use, distribution, and reproduction in any medium, for non-commercial purposes, provided the original work is properly cited.

\section{INTRODUCTION}

Many studies (e.g. Needham, 1972 and Brosius, 1991) have been conducted on the Penan community in Borneo but according to Sercombe (2010, p. 625), “...relatively little scholarly attention" is given to levels of achievement of Penan people in formal learning contexts. Sercombe (2010, p. 627) has documented that "lack of educational success" is highlighted among Penan in Sarawak and those in Brunei. Recent research by Tom, Awang, Ahmad and Ahmad (2019, p. 140) shows that Penan community is "lagging behind in many aspects especially in the field of education". Limited research on the academic achievement may contribute to lack of understanding and knowledge about the Penan's educational needs and aspirations. Therefore, to shed light on Penan education, this study highlights the demographic background of students $(\mathrm{N}=191)$ who are currently pursuing their formal education in 
SMK Long Lama (SMKLL) and SMK Marudi (SMKM). This is in order to identify the diversity of their background. These two rural public schools required the completion of primary school education regardless of students' achievement as the prerequisites for enrolment. Inevitably the distance of students' villages from schools influenced their acceptance into the schools' hostels. The study also describes the public examination results of those school leavers $(\mathrm{N}=40)$ that have completed their schooling in SMKLL and SMKM in order to examine the strength and weakness of their achievements.

According to Langub (2013), traditionally the Penan people are nomadic and their number in the island of Borneo is estimated to be around 16,000 persons. The Penan of Sarawak inhabit the most interior of the northern part of the state, living at the headwaters of two major rivers, the Rejang and the Baram (Langub, 2013). Based on the basis of dialect Needham (1972) has divided the Penan population into two categories: Eastern and Western Penan. The Eastern Penan comprises of those living roughly to the east of Baram River, while the Western Penan occupy an area around the watershed of the Rejang River and along the Silat River, a true left tributary of the Baram. There are also Penan settlements along the Tinjar River in the Baram District, along the Jelalong River and coastal area of the Bintulu District, and in the Suai-Niah area of the Miri District. In linguistic terms, these groups appear to be closely related to the Western Penan. There are minor differences between the Eastern and Western Penan, but broadly speaking, they are similar in their ways of life and in socio-economic terms and consider themselves, and are regarded by others, as one people (Langub, 2013). In the context of this paper, the focus is on the Eastern Penan living in the Baram District. Many of these Eastern Penan communities settled in villages located at the mouth (long) of rivers or streams. They are involved in subsistence economy such as farming, collecting jungle products, hunting wild animals, fishing from the rivers and make handicraft.

The students in the study hailed from 43 Penan villages in the Baram District in Miri Division. In SMKM the students came from 24 villages (e.g. Long Benalih, Long Beruang, Long Kepang and Long Lamai) while in SMKLL the students originated from 19 villages (e.g. Long Bangan, Long Latei, Long Lunyim and Long Tepen). In order to pursue their secondary education, the students are required to go to boarding schools and they have to travel either by road transport, by boats or the combination of both. Thus, fieldworks are conducted by the researcher in Penan villages, public secondary schools, and bazaars (pasen) near the schools to deepen the knowledge about education and mobility.

\section{SOCIAL CONTEXT}

Social context of this study is divided into three components: firstly, short notes and reflection on Penan based on the author's experience before $1998^{24}$; secondly, notes and reflection on Penan after the year 1998; and thirdly, the description on collaborated educational programme in the Baram District. According to Giddens and Sutton (2013), reflexivity describes the interchange between sociological research and human behaviour. In this study reflexivity is utilized to create sense of order through engagement in a wide of activities including face to face conversation and interaction via technology (e.g. phone calls, short messages, emails and WhatsApp messages). In order words, activities sharing between research participants and the researcher produced social realities in context of Penan education.

In 1992, after sitting for the Malaysia Education Certificate (SPM) examination the author visited her brother, who was working in Long Lama Sub-District Office, Baram District and stayed there for a month. During the stay the author had the opportunity to interact with Penan individuals like in the marketplace, sundry shops and on the express boats. Recalled these sporadic contacts rekindled and contribute to research interest on Penan.

\footnotetext{
${ }^{24}$ In 1998 and 2001 the author became an interim teacher in two public secondary schools. During these moments she discovered that rural students lacked learning resources (e.g. conducive classroom and good reference books) compared to urban counterparts.
} 
In January to May 1993, the author worked as a temporary teacher in SMK Belaga ${ }^{25}$ after sitting for the Higher School Certificate (STPM) examination. The author was assigned by the principal to teach the students in Transition and Form 1, who were aged between 13-14 years old. The students comprised of various Orang $\mathrm{Ulu}^{26}$ ethnic groups including the Kayan, Kenyah, Lahanan, Punan and Penan. Throughout teaching appointment, the author had the opportunity to know deeper about all her students particularly the Penan students. The author cannot recall the total numbers of Penan students in both classes but she remembers the number is more during the first few weeks of the schooling session. Almost all students in the boarding school are from the financially poor households and being far away from their families, many of younger students are not coping well because they missed their parents and craved for home-cooked food. For the Penan students after the end of the first school holiday most did not return to school. According to a male Penan student, "Penan students quitted because they had no money to come back to school" while a few "girls got married". This is not shocking because the author knew many of her former classmates and schoolmates who settled down at an early age (i.e. between 16-20 years old).

Compared to other students from different ethnic groups in the classes the author had taught, Penan students are observed slightly less active during the lessons. Through the interactions with them the author found out that significant numbers of Penan students are feeling uncomfortable with negative treatment and remarks by other students. For instance, the remarks of saying "Eh... Penan": connoting a student of being a slow learner. Prejudice and stereotype are examples of students' negative attitudes towards Penan students in classroom or even outside class. The author observed that the incidents hampered the spirit of learning among Penan students as they are not fully accustomed to formal education including the usage of English. The author reprimanded her students when they disrespect other students through bullying and making bad remarks.

Since 1998, the author interactions with the Penan are more frequent as a result of Bakun Resettlement Scheme involving 15 longhouses including her own village are resettled in Sungai Asap-Koyan, Belaga District. In most cases the interactions are influenced by socio-cultural and socio-economic activities such as cultural festivals, religious gatherings and trading.

When the researcher started her career as lecturer in UNIMAS in the early 2006, was the opportunity to rekindle her interest on Orang Ulu communities (e.g. Kayan, Kenyah and Penan) since then have influenced her research on a range of niche areas including education and health. In early March 2018, the researcher was contacted by two persons that are working with two different non-governmental organizations (NGOs) dealing with Penan in the Baram and Belaga Districts. During a meeting one of the officer said, "Several Penan students could not pursue their tertiary education after SPM and STPM. We need your help." The author decided to assist them and extend her experience on Penan's education.

Being a trained teacher, the researcher inspires to contribute to the betterment of Penan's education and she agreed to collaborate with them. Therefore, the researcher was appointed by the Bruno Manser Fond (BMF) as an educational researcher for Penan for two years (from January 2019 until December 2020), funded by the BMF. A few activities are planned between us through collaboration and the programmes are implemented at schools or local villages. These include facilitating Penan students that have missed their chance to enter college and universities to enrol in Universiti Malaysia Sarawak (UNIMAS). Under the 'Entrance Program [to UNIMAS] for Poor Students' (Kemasukan Calon Kategori B40, ${ }^{27}$ organized by the Undergraduate Students Division, UNIMAS, the researcher initiated activities to reach for individuals who had missed their chances to pursue tertiary education because they either missed the chance to apply through UPU Online or did not have access to the internet and telephone. The

\footnotetext{
${ }^{25}$ From 1986-1988, the author was pursuing formal education (from Form 1 to Form 3) in SMK Belaga. There was no Penan student in her classes (i.e. Form 1B, Form 2A and Form 3A) and the numbers of Penan's students enrolled in that school was only a few.

${ }^{26}$ Orang Ulu comprised of diverse ethnic groups including Kenyah, Kayan, Lahanan, Sekapan, Punan, Penan, Lun Bawang and Kelabit.

${ }^{27}$ According to the Report of Household Income and Basic Amenities Survey (2016), Bottom 40 (B40) refers to a household that has median income RM3000 per month.
} 
contemporary application to pursue studies in public college and universities is centralized under the UPU Online under the jurisdiction of the Ministry of Education. Out of five persons that have sent their application forms through the researcher, four persons are rejected by the Undergraduate Students Division, UNIMAS because they did not meet the basic requirements for STPM holders' admission to UNIMAS (i.e. did not obtained C or above C on General Paper (Pengajian Am) ${ }^{28}$ Only one person met the basic requirements for enrolment to study bachelor degree in UNIMAS and she had enrolled in academic session 2018/2019.

The collaboration with different organizations in relations to Penan's education took placed in February 2019 in the Baram District. The researcher teamed up with two NGOs and involved two secondary schools namely SMKLL and SMKM. Talks and workshops on education are carried out and attended by Penan's students from Form One to Form Six, aged between 13-19 years old. The title of the talk is "Penan Youth and Tertiary Education". The talks and workshops are conducted to improve the number of enrolments of Penan's students to public universities, polytechnics, community colleges and training institutes and public skills institutes. The feedback received from students and teachers showed that educational talks and workshop are beneficial because the students felt limited opportunity to listen from the experts outside of their schools or villages due to their villages' location far away in rural areas. In one of the teacher's feedback, "I am hoping such event is organized again in the future".

Each year, the numbers of offers to pursue studies in public universities, polytechnics, community colleges and training institutes and public skills institutes to young people in Malaysia with SPM, STPM, matriculation and foundation qualifications are increasing. The young population pursued their studies in a wide range of courses whether in field of science, social science, humanities, applied science and technical or skills. Although the numbers of students in Malaysia have increased in every intake in public universities, polytechnics, community colleges and training institutes and public skills institutes but the scenario is reported contradictory for the Penan's youth. ${ }^{29}$ The number of Penan's youth enrolment is less significant and partly influenced by factors such as their academic results, geographic reasons (e.g. most Penan people live in rural areas and remote regions), limited or no access to the internet, lack of information, transport problem and financial limitations.

Therefore, the talks and workshops in the Baram District among Penan students are aimed to expose the students to the importance of tertiary education; understand the changes in the world of tertiary education and education in 'modern' world; and find ways to improve the number of Penan enrolment in public universities, polytechnics, community colleges and training institutes and public skills institutes.

\section{RESEARCH METHODS}

In order to understand students' demographic profile and educational achievement of school leavers, the researcher used ethnographic techniques which include survey questionnaire, interviews and field observations. Survey is a method of research usually involving the administration of questionnaires to a population being studied and the analysis is carried out to find patterns or regularities (Giddens, 2013). The survey includes the students' gender, age, their current level of education, the name of their village, whether the internet is available in their village and the speed of the Internet, whether telephone coverage is available, the distance of the village to boarding schools, the duration of travelling in hours, type of transport used and the cost of transportation.

According to Erickson (2011, p. 11) ethnographic descriptions should not only be holistic and factually accurate but aim "to grasp the native's point of view, his relation to life, his vision of his worlds". Fieldworks are carried out in Miri, Marudi and Long Lama bazaars, SMKM and SMKLL. The

\footnotetext{
${ }^{28}$ The author will discuss why students did badly in General Paper under the findings section.

${ }^{29}$ Statistics of the number of Penan students in institution of higher learning is not available. However, in the context of UNIMAS in 2018/2019 and 2019/2020 academic sessions only three Penan students enrolled and five persons in the latter. The number is very small compared to more than 16,000 students' enrollment in UNIMAS every academic session.
} 
researcher has traveled to Penan's villages (e.g. Long Tepen and Long Tepen Pelutan) on logging roads and participated in their activities (e.g. grocery shopping and eating together).

In obtaining the examination results of Penan school leavers, the researcher contacted persons working with Penan associations and thereafter informed the school leavers (who at the time of the study are living either in their villages, working or studying in the nearby bazaars and town) about the objective of the study (i.e. to examine their academic performance).

Data are analysed inductively using thematic strategy such as the analysis of themes related to accessibility, social exclusion and social interaction. Data on demographic profile of students and the results of school leavers are analysed with Microsoft Excel. Data related to examination results are analysed based on the guidelines from the Malaysia Education Council (Majlis Peperiksaan Malaysia), for instance, to the need to pass History subject as one of the conditions to obtain SPM certificate.

\section{FINDINGS AND DISCUSSION}

This section highlights the demographic profile of students $(\mathrm{N}=191)$ and academic results of their school leavers $(\mathrm{N}=40)$.

\section{Demographic Profile of Students}

Table 1 shows the demographic profile of Penan students that are still schooling in the respected public secondary schools. These include their gender and the level of their education.

Table 1: Students' gender and educational level

\begin{tabular}{|c|c|c|c|c|c|c|c|c|c|}
\hline \multirow[t]{3}{*}{ School } & \multirow{3}{*}{$\begin{array}{c}\text { Respondents } \\
\mathrm{N}=191\end{array}$} & \multicolumn{2}{|c|}{ Gender } & \multicolumn{6}{|c|}{ Educational level } \\
\hline & & \multirow[t]{2}{*}{ Female } & \multirow[t]{2}{*}{ Male } & $\begin{array}{c}\text { Form } \\
1\end{array}$ & $\begin{array}{c}\text { Form } \\
2\end{array}$ & $\begin{array}{c}\text { Form } \\
3\end{array}$ & $\begin{array}{c}\text { Form } \\
4\end{array}$ & $\begin{array}{c}\text { Form } \\
5\end{array}$ & $\begin{array}{c}\text { Form } \\
6\end{array}$ \\
\hline & & & & \multicolumn{3}{|c|}{70} & \multicolumn{3}{|c|}{121} \\
\hline SMKLL & 115 & 61 & 54 & 16 & 11 & 21 & 34 & 29 & 4 \\
\hline SMKM & 76 & 52 & 24 & 9 & 8 & 5 & 25 & 25 & 4 \\
\hline \multirow{2}{*}{\multicolumn{2}{|c|}{ Total }} & 113 & 78 & 25 & 19 & 26 & 59 & 54 & 8 \\
\hline & & \multicolumn{2}{|c|}{191} & \multicolumn{3}{|c|}{70} & \multicolumn{3}{|c|}{121} \\
\hline
\end{tabular}

Sixty percent (115 students) are studying in SMKLL while 39.8\% (76 students) are studying in SMKM. $59.2 \%$ (113 students) are females, while $40.8 \%$ (78 students) are males.

Sixty three percent (121 students) are studying in Form 4-6 while 36.6\% (70 students) are studying in Form 1-3. The total number of students enrolled in lower secondary schools is less in part because Penan students can opt to attend Form 1-3 in rural secondary schools that are closer to their villages such as SMK Bario, SMK Tinjar and SMK Temenggong Datuk Lawai Jau.

A few Penan students with flying colours results are reported to be studying in 'special' boarding schools in Miri. These types of boarding schools (e.g. Sekolah Berasrama Penuh (SBP) or Maktab Rendah Sains MARA (MRSM) received students with excellent results in the 'Primary School Assessment Test' (UPSR) and 'Lower Secondary Assessment' (PMR). This illustrates that, UPSR result determines the direction of a student's future after finishing primary education. A straight A's result opens opportunities for students to attend quality schools such as SBP or MRSM. In this context, schools are important means to improve the mobility of students in the future as some will complete their secondary education and because of their good results will be accepted to the best universities in Malaysia and abroad. 


\section{Demographic profile of school leavers}

Table 2 shows the demographic profile of Penan school leavers: 29 persons (72.5\%) have SPM qualifications and 11 persons $(27.5 \%)$ have STPM qualifications.

The age of the school leavers is between $19-27$ years old. $87.5 \%$ (35 persons) are single, while $12.5 \%$ (5 persons) are married. Most school leavers are single in line with the report by the Department of Statistics Malaysia (2017) which stated that median age of married: 29 for male and 26 for female.

Table 2: Age, Gender, Academic Qualification and Marital Status of School Leavers

\begin{tabular}{|c|c|c|c|c|}
\hline School Leaver & Age & $\begin{array}{c}\text { Academic } \\
\text { Qualification }\end{array}$ & Gender & Marital Status \\
\hline 1 & 21 & SPM & Female & Single \\
\hline 2 & 24 & SPM & Male & Single \\
\hline 3 & 22 & SPM & Female & Married \\
\hline 4 & 22 & SPM & Female & Single \\
\hline 5 & 22 & SPM & Female & Single \\
\hline 6 & 27 & SPM & Male & Married \\
\hline 7 & 25 & SPM & Male & Single \\
\hline 8 & 24 & SPM & Female & Single \\
\hline 9 & 27 & SPM & Male & Single \\
\hline 10 & 25 & SPM & Female & Single \\
\hline 11 & 27 & SPM & Female & Married \\
\hline 12 & 26 & SPM & Female & Single \\
\hline 13 & 25 & SPM & Female & Single \\
\hline 14 & 25 & SPM & Female & Single \\
\hline 15 & 20 & SPM & Female & Single \\
\hline 16 & 22 & SPM & Female & Single \\
\hline 17 & 25 & SPM & Male & Single \\
\hline 18 & 24 & SPM & Female & Married \\
\hline 19 & 20 & SPM & Male & Single \\
\hline 20 & 22 & SPM & Female & Single \\
\hline 21 & 22 & SPM & Female & Single \\
\hline 22 & 25 & SPM & Female & Single \\
\hline 23 & 19 & SPM & Male & Single \\
\hline 24 & 27 & SPM & Female & Single \\
\hline 25 & 19 & SPM & Male & Single \\
\hline 26 & 24 & SPM & Female & Single \\
\hline 27 & 25 & SPM & Male & Married \\
\hline 28 & 21 & SPM & Female & Single \\
\hline 29 & 26 & SPM & Female & Single \\
\hline 30 & 20 & STPM & Female & Single \\
\hline 31 & 22 & STPM & Female & Single \\
\hline 32 & 22 & STPM & Female & Single \\
\hline 33 & 22 & STPM & Female & Single \\
\hline 34 & 24 & STPM & Male & Single \\
\hline 35 & 25 & STPM & Female & Single \\
\hline
\end{tabular}




\begin{tabular}{|l|l|l|l|l|}
36 & 26 & STPM & Female & Single \\
\hline 37 & 27 & STPM & Male & Single \\
\hline 38 & 22 & STPM & Female & Single \\
\hline 39 & 23 & STPM & Female & Single \\
\hline 40 & 22 & STPM & Male & Single \\
\hline
\end{tabular}

In relation to gender of the school leavers 70\% (28 persons) are female and 30\% (12 persons) are male. Females outnumbered males demonstrated in the statistic of enrolment (refer Table 1 for details) in which significant number of females enrolled in respective secondary schools compared to males.

In respect to age group, the school leavers are aged between 19-27 years old. This age group is classified as youth in Malaysia because based on the National Youth Development Policy, youth are people who are aged between $15-40$ years old.

\section{From village to boarding schools}

All the students that left their villages in order to study in the public secondary schools, namely SMKLL and SMKM, are staying in the schools' hostels. Mobility as demonstrated in the students' movement are from rural areas to bazaar areas because most secondary schools in Sarawak are located in bazaars areas, and towns and cities. In the cases of SMKLL, students from 19 villages have been enrolled at the school, while SMKM has received and enrolled students from 24 different villages.

The boarding schools are equipped with basic amenities and facilities which include beds, mattresses, pillows, electricity and treated clean water. Daily breakfast, lunch and dinner are provided to the boarders and this helped to reduce financial burden among the students. However, they still need financial support from their families to purchase other items such as books, stationeries, toiletries and other personal needs. Based on the researcher interactions with female boarders they need between RM100-150 per month in order to be able to "purchase" their daily needs.

The journey by roads from the students' villages to boarding schools ranged between 90 minutes to sixhours journey. ${ }^{30}$ For instance, four students in SMKLL (three persons from Ba Pakan and one student from Long Latei) have to travel six hours to reach their boarding schools. A great significant number of roads that the students travelled on to and fro between their villages and the schools are logging roads or poorly maintained roads, and in most cases are without road signage for direction. Although, most of the students have stated that they get free rides in logging or plantations companies' vehicles to and fro to the boarding schools, they still have to endure a range of challenges such as bad road conditions, packed vehicles, and risky journeys. Sadly, often times many have to sit at the back of a four-wheel transport while plying on dusty logging or plantations roads and at times are soaked wet if it rains. For safety purposes, most of the students, especially the female students have to travel in groups.

On top of the difficulties and painful journeys to boarding schools in SMKLL and SMKM, many students have to pay between RM10-40 per journey. The total cost per student for transportation fees and food for a to and fro journey is RM30-50. Therefore, in order to reduce cost, most students will only return to their villages during the long semester breaks.

For those students from Long Lamai, the travel to and fro school involves a combination of different means of transportation. For example, a journey back and forth will involves travelling both by boat and by four-wheel vehicles. And the availability of these transportation is affected by unpredictable factors such as heavy rain, flood, landslides and road collapse.

\footnotetext{
${ }^{30}$ Most of the respondents do not know how to measure the distance in terms of kilometer due to unavailable signboard, poorly displayed signage for direction and that there are roads without signs at all.
} 


\section{Internet access and telephone connectivity}

According to Bakhshi and Oliver (2013, p. 5), the notion of access encompasses a myriad of factors, which are directly or indirectly linked to the education processes and outcomes. In this section, the link between internet access and education is explained but the outcomes of these processes is expected to be covered in future research.

Table 3a shows the villages' access to the internet and telephone. Only five villages (11.6\%) out of 43 Penan villages have access to the internet and telephone. The five villages are Long Lamai, Long Beruang, Long Sait, Long Kevok and Long Latei. Long Lamai is the first Penan village in Baram to enjoy the internet service in year 2016 whilst the other four villages are reported received the service: between the year 2017 to 2018. The internet and telephone service are either provided by the government or private company. The speed of the internet is rated slow and average. Another 38 villages (88.4\%) have no access to the internet and telephone. With no access to the internet and telephone, Penan villagers are experiencing social exclusion. The Commission of European Communities defined social exclusion as "the multiple and changing factors which result in people being excluded from the normal exchanges, practices, and rights of modern society" (Mannion, 2005, p. 87).

Table 3a: Villages access to the internet and telephone

\begin{tabular}{|l|l|c|c|}
\hline \multicolumn{2}{|c|}{} & Number of villages & Percentage (\%) \\
\hline $\begin{array}{l}\text { Villages Access to the } \\
\text { Internet and Telephone }\end{array}$ & No Access & 38 & 88.4 \\
\cline { 2 - 4 } & $\begin{array}{l}\text { Access } \\
\text { Available }\end{array}$ & 5 & 11.6 \\
\hline & Total & $\mathbf{4 3}$ & $\mathbf{1 0 0}$ \\
\hline
\end{tabular}

With the access to the internet and telephone in five villages the family members of students can interact with their children in boarding schools more frequently. However, the family members of those students without the access to the internet and telephone in 38 villages are using different means of communication such as letters and the passing of messages verbally.

Table 3b: Students access to the internet and telephone in their villages

\begin{tabular}{|l|l|c|c|}
\hline \multicolumn{2}{|l|}{} & Students & $\begin{array}{c}\text { Percentage } \\
(\%)\end{array}$ \\
\hline $\begin{array}{l}\text { Students Access to the Internet } \\
\text { and Telephone in their villages }\end{array}$ & No Access & 154 & 80.6 \\
\cline { 2 - 4 } & $\begin{array}{l}\text { Access } \\
\text { Available is }\end{array}$ & 37 & 19.4 \\
\hline \multicolumn{1}{|r|}{ Total } & $\mathbf{1 9 1}$ & $\mathbf{1 0 0}$ \\
\hline
\end{tabular}

Table $3 \mathrm{~b}$ shows $80.6 \%$ (154 students) do not have access to the internet and telephone when they returned to their villages and these students live in households without those accesses. About $19.4 \%$ (37 students) have the access to the internet and telephone when they returned to their villages. This is either by utilizing the internet access available in telecentres nearby or using their own internet data.

When returned to boarding schools in SMKLL and SMKM, students who own hand phones are not allowed to bring their hand phones as stipulated in the schools' rules and regulations. Having said that, Form 6 student boarders who have laptops are allowed to bring their laptops to their schools. With that, student boarders who are without mobile phones and neither laptops, are allowed to access and use the computers available at the school general office buildings or at the resource centres to access the internet.

Majority of the students who do not own personal computers claimed that they cannot afford the gadgets. This is a challenge for these students. Although the school computers with internet access are available in the general office or resource centres the numbers of computers however are not enough to cater for the number of students, therefore students have to take turn to use the facilities. Sometimes the situation 
requires them to do advance booking. Furthermore, the facilities in resource centres are normally catered for teachers and students during schooling sessions, for instance for viewing of documentaries and participating in online lessons.

The lack of internet access greatly affects students' integration into formal learning. This is because the unavailability of internet access in their villages can influence the students' decisions whether or not to move to bazaars areas (i.e. SMKLL and SMKM) that have better internet speed and coverage. The need to sustain "being socially connected" with other people have put financial strain on them to purchase internet data.

\section{Against all odds: Acquiring formal education}

In Malaysia education is seen as a catalyst for increased upward mobility. In order to escape the cycle of poverty, education is one of the most effective tools to do so. This is because education increases social mobility and will translate to a better quality of life for individuals.

All the students have to endure many difficulties and challenges in order to obtain formal education. Muhd Amirul Faiz Ahmad (2012) highlighted that Encik Ezra Uda, ${ }^{31}$ the first Penan that has entered public university (i.e. UNIMAS) had against all odds in getting formal education including walking through the jungle for a week to reach school and these challenges have motivated and inspired him. In one of the student's words, their patience is tested to the highest limit to obtain formal education outside the village:

"Every time my mother and I woke early. We cooked rice and dish. We left home early so that I can get the ride from company transport [logging company]. We wait patiently at the junction. Normally between 7.00 a.m. to 12.00 p.m. If there is no transport after 12.00 noon we come again the next day. Sometimes I feel frustrated... waiting too long but my mother reminded be to be patient". (Urai, 22 years old).

All students said that they have to travel in groups (e.g. with persons from the same village or siblings) to and fro between their schools and villages for they are concerned about their safety and security. This is especially amongst female students because 'bad things' can happen anytime such as being stranded on logging roads due to vehicles breakdown, or, could be due to an accident or damage road. Because of that parents often advised their children not to travel alone especially that there have been cases of Penan girls being sexually molested (Chin, 2012).

\section{Education attainment of Penan school leavers}

As mentioned earlier, 29 school leavers have obtained SPM qualifications and 11 have attained STPM qualifications. The SPM holders have sat for their examination between the years 2009-2017 while STPM holders have sat for the examination between the years 2011-2018.

\section{School leavers' SPM results and summary}

Table 4a shows that majority of the school leavers have enrolled in the Art Stream in SMKLL and SMKM. The small numbers of school leavers who have enrolled themselves in Science Stream reflect the concerns raised by the President of the People's Association for Development and Education of Penan (PADE). In fact, in 2015 none of the Penan students have enrolled into the Science Stream at Form 4, as all of them have entered the Arts stream (Crucial to give Penan students full scholarships, 2015).

Based on the analysis of 6 core subjects that are crucial for SPM examination, the results show that the school leavers did better in subjects such as Malay language, Moral Studies, History and Science. Malay language is the medium of instruction for all subjects in schools except for during English classes. Malay language is also used to interact with other students, teachers and other general populations.

\footnotetext{
${ }^{31}$ Currently Encik Ezra Uda is working as Sarawak Administrative Officer in Miri.
} 
However, most school leavers scored unsatisfactory achievement levels in English and Mathematics. For example, 4 school leavers (13.8\%) failed their English and a school leaver (3.4\%) failed Mathematics. School leavers' weak level of achievement in English and Mathematics are similarly observed among other Orang Ulu students in primary and secondary schools elsewhere in rural areas. School leavers poor English proficiencies are influenced by many factors including school leavers' parents do not speak English, limited access to English resources (e.g. books and digital resources), lack of confident to converse in English and limited opportunities to speak English in different social environment. School leavers' English achievement maybe explained in the context of Penan in Sukang, in the southern part of Brunei:

"When individuals from small, as well as socially, politically and generally economically vulnerable groups enter formal education, they are almost inevitably immersed in school settings where the medium (or media) of instruction are either second or foreign languages, and where they receive little or no second or foreign language support for their immersion or, rather, submersion experience". (Sercombe, 2010, p. 625)

Sercombe (2010) calls for construction and deconstruction of knowledge on Penan education. These include rethinking of national education policies and the implementation of the policies which are culturally relevant to minority groups. The author will discuss this further under concluding section.

Table 4a and Table $4 \mathrm{~b}$ show the SPM results of the school leavers and the summary of the results. None of the school leavers fail Malay language, Moral Studies, History and Science. None of the school leavers achieve A+ (Excellent or the Highest) in all subjects they have sat for but a few school leavers failed English and Mathematics.

Significant number of school leavers are concerned with their results because they may affect their opportunity to pursue their studies or in getting a job in public or private sectors. Majority of school leavers acknowledged that formal education contributes to upward social mobility as demonstrated in the success of other ethnics such as the Kayan, Kenyah and Kelabit.

For school leavers that have enrolled in Science Stream in Form 4 and Form 5, in addition to Malay language, English, Moral Studies, History and Mathematics, they took science-related subjects such as Additional Mathematics, Physic, Chemistry and Biology but scored between Grade E (Pass) to Grade $\mathrm{C}$ (Credit). School leavers admitted that they are struggling financially and academically in part because reference books are expensive and significant numbers of learning materials are in English language. According to Sercombe (2010), individuals from linguistic marginalized groups need to become proficient in English (as well as Malay), if they are to succeed academically.

Table 4a: School Leavers' SPM Results

\begin{tabular}{|c|l|c|c|c|c|c|c|}
\hline School Leaver & Option Taken & Malay & English & Moral & History & Mathematics & Science \\
\hline 1 & Art Stream & B + & C & B + & C & E & B + \\
\hline 2 & Art Stream & B & F & B & C & D & B \\
\hline 3 & Art Stream & C & E & B & C & E & B + \\
\hline 4 & Art Stream & B + & D & B+ & B & D & A \\
\hline 5 & Art Stream & B + & D & B & D & D & C+ \\
\hline 6 & Art Stream & B & D & A- & C+ & C + & A \\
\hline 7 & Art Stream & C & F & C + & C & D & C + \\
\hline 8 & Art Stream & C + & D & B+ & C & D & B \\
\hline 9 & Science Stream & B & D & B + & B & B + & SnT $^{32}$ \\
\hline
\end{tabular}

32 Subject not Taken (SnT) by students in Science Stream 


\begin{tabular}{|c|c|c|c|c|c|c|c|}
\hline 10 & Art Stream & $\mathrm{B}$ & $\mathrm{C}+$ & A- & $\mathrm{B}+$ & $\mathrm{D}$ & $\mathrm{B}$ \\
\hline 11 & Science Stream & A- & $\mathrm{C}+$ & $\mathrm{B}+$ & $\mathrm{C}$ & $\mathrm{C}$ & $\mathrm{SnT}$ \\
\hline 12 & Science Stream & $\mathrm{B}+$ & $\mathrm{B}$ & A- & A- & $\mathrm{D}$ & $\mathrm{SnT}$ \\
\hline 13 & Art Stream & $\mathrm{B}+$ & $\mathrm{C}$ & $\mathrm{B}+$ & $\mathrm{B}+$ & $\mathrm{D}$ & $\mathrm{B}+$ \\
\hline 14 & Art Stream & $\mathrm{D}$ & $\mathrm{F}$ & $\mathrm{C}+$ & $\mathrm{E}$ & $\mathrm{D}$ & $\mathrm{C}$ \\
\hline 15 & Art Stream & $\mathrm{B}$ & $\mathrm{D}$ & $\mathrm{A}$ & $\mathrm{B}$ & $\mathrm{E}$ & $\mathrm{B}$ \\
\hline 16 & Art Stream & $\mathrm{B}$ & $\mathrm{E}$ & A- & $\mathrm{B}$ & $\mathrm{D}$ & $\mathrm{B}$ \\
\hline 17 & Art Stream & $\mathrm{E}$ & $\mathrm{D}$ & $\mathrm{E}$ & $\mathrm{E}$ & $\mathrm{F}$ & $\mathrm{D}$ \\
\hline 18 & Art Stream & A & $\mathrm{D}$ & $\mathrm{B}+$ & $\mathrm{B}$ & $\mathrm{D}$ & $\mathrm{B}+$ \\
\hline 19 & Art Stream & $\mathrm{B}$ & $\mathrm{D}$ & $\mathrm{C}+$ & $\mathrm{C}+$ & $\mathrm{E}$ & $\mathrm{B}+$ \\
\hline 20 & Art Stream & $\mathrm{C}$ & $\mathrm{F}$ & $\mathrm{C}+$ & $\mathrm{E}$ & $\mathrm{E}$ & $\mathrm{D}$ \\
\hline 21 & Art Stream & $\mathrm{B}$ & $\mathrm{D}$ & $\mathrm{A}$ & $\mathrm{B}$ & $\mathrm{D}$ & $\mathrm{A}$ \\
\hline 22 & Art Stream & $\mathrm{A}$ & $\mathrm{B}+$ & $\mathrm{B}+$ & $\mathrm{B}+$ & $\mathrm{D}$ & $\mathrm{B}+$ \\
\hline 23 & Art Stream & $\mathrm{B}$ & E & $\mathrm{B}$ & $\mathrm{C}+$ & $\mathrm{E}$ & $\mathrm{E}$ \\
\hline 24 & Art Stream & $\mathrm{C}$ & $E$ & $\mathrm{~B}$ & $\mathrm{D}$ & $\mathrm{E}$ & $\mathrm{D}$ \\
\hline 25 & Art Stream & $\mathrm{B}+$ & $\mathrm{D}$ & A- & $\mathrm{B}$ & $\mathrm{B}$ & $\mathrm{D}$ \\
\hline 26 & Art Stream & A- & $\mathrm{D}$ & $\mathrm{B}+$ & $\mathrm{B}+$ & $\mathrm{D}$ & A- \\
\hline 27 & Art Stream & $\mathrm{B}$ & $E$ & $\mathrm{~B}+$ & $\mathrm{C}$ & $\mathrm{D}$ & $\mathrm{C}+$ \\
\hline 28 & Art Stream & A- & $\mathrm{D}$ & $\mathrm{B}+$ & $\mathrm{C}$ & $\mathrm{C}+$ & $\mathrm{C}+$ \\
\hline 29 & Science Stream & $\mathrm{B}$ & $\mathrm{C}+$ & A- & $\mathrm{B}$ & $\mathrm{A}$ & $\mathrm{SnT}$ \\
\hline
\end{tabular}

One of the most interesting finding in relations to the SPM results of the school leavers is that they scored between Grade C+ and A in Moral Studies. Moral Studies is a compulsory subject only for the non-Muslim students in Malaysia and school leavers' results suggest that moral values (nilai) such as co-existence, mutual respect, responsibility, tolerance and obedience to law are internalized or contextualized by the school leavers.

Table 4b: Summary of School Leavers' SPM Results

\begin{tabular}{|c|c|c|c|c|c|c|c|}
\hline \multirow{2}{*}{ Grade } & $\begin{array}{c}\text { Level of } \\
\text { Achievement }\end{array}$ & \multicolumn{7}{|c|}{ Subject } \\
\cline { 3 - 8 } & Malay & English & $\begin{array}{l}\text { Moral } \\
\text { Education }\end{array}$ & History & Mathematics & Science \\
\hline A+ & $\begin{array}{c}\text { Excellent } \\
\text { (Highest) }\end{array}$ & 0 & 0 & 0 & 0 & 0 & 0 \\
\hline A & $\begin{array}{c}\text { Excellent } \\
\text { (Higher) }\end{array}$ & 2 & 0 & 2 & 0 & 1 & 3 \\
\hline A- & Excellent (High) & 3 & 0 & 6 & 1 & 0 & 1 \\
\hline B+ & Credit (Highest) & 6 & 1 & 11 & 4 & 1 & 6 \\
\hline B & Credit (Higher) & 11 & 1 & 5 & 8 & 1 & 5 \\
\hline C+ & Credit (High) & 1 & 3 & 4 & 3 & 2 & 4 \\
\hline C & Credit & 4 & 2 & 0 & 8 & 1 & 1 \\
\hline D & Pass & 1 & 13 & 0 & 2 & 15 & 4 \\
\hline E & Pass & 1 & 5 & 1 & 3 & 7 & 1 \\
\hline F & Fail & 0 & 4 & 0 & 0 & 1 & 0 \\
\hline & & \multicolumn{7}{l|l}{ Subject not Taken (SnT) } \\
\hline
\end{tabular}




\section{School leavers' STPM results and summary}

Table 5a and Table 5b show the results and summary of school leavers with STPM qualifications. The average Cumulative Grade Point Average (CGPA) for the 8 school leavers is 2.60. School leavers' results are significantly weak in General Paper (Pengajian Am) and three persons achieved 'Partial Pass' (i.e. C-, D and E). With 'Partial Pass' in General Paper, the school leavers will have no chance to pursue their bachelor degree through STPM admission into public universities. Data from observation shows that lack of good reference books and limited opportunity to discuss about national current issues at household and community levels contributing to weak achievement of school leavers in General Paper. However, the school leavers did well in Visual Art and all achieved 'Fully Pass'. Similarly, the results of subjects such as Malay language and History are significant better for most school leavers.

All the school leavers with STPM qualifications have sat for the Malaysian University English Test (MUET) as a requirement to pursue their bachelor degree in the public universities. In MUET people are tested in four components: listening, speaking, reading and writing. Majority of the STPM holders are categorized under 'Very Limited User (Band 1) to Limited User (Band 2)'. In the context of communicative ability, a 'Very Limited User' hardly able to use English; in respect to comprehension, a 'Very Limited User' has very limited understanding of language and its context; and has very limited ability to function in the language in relations to task performance.

Table 5a: School leavers' STPM results

\begin{tabular}{|c|c|c|c|c|c|c|c|c|}
\hline Gender & Age & $\begin{array}{c}\text { General } \\
\text { Paper }\end{array}$ & Malay & History & $\begin{array}{c}\text { Visual } \\
\text { Art }\end{array}$ & $\begin{array}{c}\text { Business } \\
\text { Studies }\end{array}$ & CGPA & MUET \\
\hline Female & 20 & B- & B- & B- & C+ & & 2.59 & Band 2 \\
\hline Female & 22 & C- & B- & C & A- & & 2.50 & Band 2 \\
\hline Female & 22 & C & B- & C+ & B- & & 2.42 & Band 3 \\
\hline Female & 22 & C- & B- & B- & A & & 2.75 & Band 2 \\
\hline Male & 24 & C- & C & C+ & B+ & & 2.33 & Band 1 \\
\hline Female & 25 & C & B & B+ & & C+ & 2.67 & Band 2 \\
\hline Female & 26 & A- & B & B- & C & & 2.84 & Band 2 \\
\hline Male & 27 & C+ & B- & B- & B+ & & 2.79 & Band 2 \\
\hline Female & 22 & C & B+ & C & A- & & 2.59 & Band 2 \\
\hline Female & 23 & B- & B- & B- & B+ & & 2.84 & Band 2 \\
\hline Male & 22 & C & B & B- & B- & & 2.59 & Band 2 \\
\hline
\end{tabular}


Table 5b: Summary of School Leavers' STPM Results

\begin{tabular}{|c|c|c|c|c|c|c|c|}
\hline $\begin{array}{c}\text { Grade } \\
\text { Point }\end{array}$ & $\begin{array}{c}\text { Grade } \\
\text { Point }\end{array}$ & $\begin{array}{c}\text { Achievement } \\
\text { Level }\end{array}$ & $\begin{array}{c}\text { General } \\
\text { Studies }\end{array}$ & Malay & History & $\begin{array}{c}\text { Visual } \\
\text { Art }\end{array}$ & $\begin{array}{c}\text { Business } \\
\text { Studies }\end{array}$ \\
\hline A & 4.00 & Full Pass & 0 & 0 & 0 & 1 & \\
\hline A- & 3.67 & Full Pass & 1 & 0 & 0 & 2 & \\
\hline B+ & 3.33 & Full Pass & 0 & 1 & 1 & 3 & \\
\hline B & 3.00 & Full Pass & 0 & 3 & 0 & 1 & \\
\hline B- & 2.67 & Full Pass & 2 & 6 & 6 & 1 & \\
\hline C + & 2.33 & Full Pass & 1 & 0 & 2 & 1 & 1 \\
\hline C & 2.00 & Full Pass & 4 & 1 & 2 & 1 & \\
\hline C- & 1.67 & Partial pass & 3 & 0 & 0 & 0 & \\
\hline D & 1.33 & Partial pass & 0 & 0 & 0 & 0 & \\
\hline E & 1.00 & Partial pass & 0 & 0 & 0 & 0 & \\
\hline F & 0.00 & Fail & 0 & 0 & 0 & 0 & \\
\hline
\end{tabular}

\section{CONCLUSION}

Data from this study show that access to a wide range of social services including good education, quality roads and transportation, and the availability of up-to-date telecommunication technology is crucial for all people, including marginalized populations and in this case the Penan students. Access to these facilities, services and technologies are necessary to address social exclusion. According to Bakhshi and Oliver (2013), access can include physical accessibility (e.g. transport) as well as inclusive modes of learning that can be adapted to the needs of the child; the ability of teachers and school staff of rural school settings to adapt information and processes; the attitudes of children and their parents, as well as communities and decision makers; the beliefs of the family; and policies and state incentives that encourage social inclusion and cohesion.

Drawing from the study's the author call for respective people including policy makers and implementers, researchers and educationists to rethink of the Penan education. With limited access to safe roads and mode of transportation and limited access to the internet in the villages the Penan will continue to be excluded from a range of services that are taken by granted by modern society especially of those in urban areas. In the context of this study, the access to the internet and telephone is only available to five villages out 43 villages in the Baram District. In other words, access to social services is crucial because access is linked to the availability, affordability and acceptability of any service, $p$. whether a service is available at a particular time and at a particular place, whether people can pay for the service and whether the service is available.

However, it is important to remember that there is variation of needs amongst students. For instance, data on the demographic profile of students that are still studying in SMKLL and SMKM suggest that the needs of students are diverse. This includes the need for more financial support for students that hailed from villages that are located far away from boarding schools (e.g. Long Lamai). This is mainly due to high cost of transportation, and also the need to purchase more learning materials for students in upper secondary schools (e.g. Form 5 and Form 6). Meanwhile, the needs of Penan students (e.g. Form 1-3 and Form 4-6) are different for they are mainly emotional and social. Parents of the students and their teachers at the schools are expected in meeting these needs.

Without access to the internet and telephone at the 38 villages, self-directed learning through the internet cannot take place. This is so when 154 students returned to their villages during long school holidays. Because of the absence of access to the internet, students from these villages also felt excluded and disconnected from their social networks. 
Data on school leavers' results also suggest the need of collaboration at all levels (individual, household, community and national) to address low rates of academic attainment among Penan children. These include at the individual level Penan students could be informed in which subjects they are good at and which subjects they weak at and therefore they have to put extra attention on weak subjects. Since most Penan children are "...frequently unwilling to take centre stage because it is often interpreted as boastful behavior and be frowned on in Penan society (Sercombe, 2010, p. 631), this paper calls for a shift of thinking on this aspect at individual and household levels. Penan parents should stress on their children achievement in academic, sports and other school-related activities (Sercombe, 2010, p. 631).

As most Penan adults or parents are financially poor (Sercombe, 2010), their households need the support for socio-economic programmes to alleviate poverty such as innovate way to market Penan products such as handicrafts and jungle produce. Rethinking Penan education also require rethinking activities related to oil palm plantations and logging activities in their areas that directly impact their livelihood such as forests clearance diminish the source of income of Penan families and subsequently affect the ability of parents to financially support their children education. The researcher travels to both Baram and Belaga Districts show that commercial plantations and logging companies are significantly interested in making profit and ignored a wide range of issues including good road, clean water supplies and food security. As such natural environment including jungle and river are crucial to the Penan because many are complete reliance on wild resources (Janowski and Langub, 2011) and "... they are against development that disrupts their livelihood and activities" (Selvadurai et al., 2013).

Based on observation small numbers of Penan teachers are teaching or working in primary and secondary schools in Penan areas and therefore the relevant authority or agencies could recruit more Penan school leavers to pursue their education or training in education so that after they have graduated they could be posted to work in their own communities. Government agencies and private sectors also could offer job opportunities to Penan graduates so that they could inspire Penan children to excel in education because education is important for upward mobility and in order for these graduates to contribute back to the communities. Recruitment of Penan graduates is crucial because the data from this study revealed that "three persons with diploma and four persons with bachelor degree qualifications" are unemployed and therefore there is a need for future research on this aspect. These trends and patterns reflect the importance of education as a catalyst for increased upward mobility in Malaysia. In this case, access to good schools which can guarantee good examination results education is one of the most effective tools to do so. Ultimately access to good education pave the way for many individuals at the fringe of the national development planning to escape the cycle of poverty, increases social mobility and attain a better quality of life.

\section{ACKNOWLEDGMENT}

I would like to thank my colleague, Dr Adam Andani Mohammed of Faculty of Social Sciences and Humanities, UNIMAS for reviewing this article.

The study is funded by the BMF. 


\section{REFERENCES}

Bakhshi P, Kett M, Oliver K. (2013). What are the impacts of approaches to increase the accessibility to education for people with a disability across developed and developing countries and what is known about the cost-effectiveness of different approaches? EPPI-Centre, Social Science Research Unit, Institute of Education, University of London.

Brosius, J.P. (1991). Foraging in tropical rain forests: The case of the Penan of Sarawak, East Malaysia (Borneo). Human Ecology, 19(2), 123-52.

Crucial to give Penan students full scholarships (2015, June 1), Borneo Post Online. https://www.theborneopost.com/2015/06/01/crucial-to-give-penan-students-full-scholarships/

Chin, M.Y. (2012, March 5). Education a lifeline for Penan kids. The Star Online. https://www.thestar.com.my/lifestyle/features/2012/03/05/education-a-lifeline-for-penan-kids

Erickson, F. (2011). A history of qualitative inquiry in social and educational research. In N. K. Denzin and Y.S. Lincoln (Eds.), The Sage handbook of qualitative research Vol. 4 (pp. 43-60). Sage Publications.

Department of Statistics Malaysia. (2018). Divorce and Marriage Statistics. https://www.dosm.gov.my

Giddens, A. and Sutton, P.W. (2013). Sociology. (7th Edition). Polity Press.

Janowski, M. and Langub, J. (2011). Footprints and marks in the forest: The Penan and the Kelabit of Borneo. In G. Barker and M. Janowski (Eds.), Why Cultivate? Anthropological and archaeological approaches to foraging-farming transitions in Southeast Asia (pp. 121-32). McDonald Institute for Archaeological Research.

Langub, J. (2013). Tamu: institutionalized barter trade, the Penan and their encounter with the colonial and post-colonial state. Borneo Research Bulletin, 44, 178-192.

Mannion, G. (2005). Education and learning for social inclusion. In M. Barry (Ed.), Youth policy and social inclusion: Critical debates with young people. (pp. 73-91). Routledge.

Muhd Amirul Faiz Ahmad (2012, April 10). Anak Penan pertama masuk 'U'. Berita Harian, p. 12. https://ir.unimas.my/id/eprint/5917/

Needham, R. (1972). Penan. In F. LeBar (Ed.) Ethnic groups of insular Southeast Asia, Vol. 1 (pp. 176180). Human Relations Area Files Press.

Sercombe, P.G. (2010). Language and education: The experience of the Penan in Brunei. International Journal of Education Development, 30, 625-635.

Selvadurai, S, Er, A.C., Lyndon, N., Sum, S. M., Saad, S., Manaf, A. A., and Ramli, Z. (2013). Penan natives' discourse for and against development. Asian Social Science, 9(8), 72-78.

Tom, R.A., Awang, M.M., Ahmad, A.R. and Ahmad, A. (2019). The national policy from the point of view (weltaunchauung) of the Penan community. In Noordin, N. and Ngadnon, N. (Eds.) Global Conference Series: Social Sciences, Education and Humanities (GCS:SSEH Vol 2) (pp. 140-143). https://series.gci.or.id 